\title{
Development of microsatellite markers for identifying Brazilian Coffea arabica varieties
}

\author{
Elisa S.N. Vieira ${ }^{1}$, Édila V. de R. Von Pinho ${ }^{2}$, Maria G.G. Carvalho ${ }^{2}$, Danny G. Esselink ${ }^{3}$ and Ben $\operatorname{Vosman}^{3}$ \\ ${ }^{1}$ Cooperativa Central de Pesquisa Agrícola, Núcleo de Biotecnologia, Cascavel, PR, Brazil. \\ ${ }^{2}$ Universidade Federal de Lavras, Departamento de Agricultura, Lavras, MG, Brazil. \\ ${ }^{3}$ Plant Research International, Wageningen UR Plant Breeding, Wageningen, The Netherlands.
}

\begin{abstract}
Microsatellite markers, also known as SSRs (Simple Sequence Repeats), have proved to be excellent tools for identifying variety and determining genetic relationships. A set of 127 SSR markers was used to analyze genetic similarity in twenty five Coffea arabica varieties. These were composed of nineteen commercially important Brazilians and six interspecific hybrids of Coffea arabica, Coffea canephora and Coffea liberica. The set used comprised 52 newly developed SSR markers derived from microsatellite enriched libraries, 56 designed on the basis of coffee SSR sequences available from public databases, 6 already published, and 13 universal chloroplast microsatellite markers. Only 22 were polymorphic, these detecting 2-7 alleles per marker, an average of 2.5. Based on the banding patterns generated by polymorphic SSR loci, the set of twenty-five coffee varieties were clustered into two main groups, one composed of only Brazilian varieties, and the other of interspecific hybrids, with a few Brazilians. Color mutants could not be separated. Clustering was in accordance with material genealogy thereby revealing high similarity.
\end{abstract}

Key words: SSR, coffee, genetic similarity, molecular marker.

Received: March 10, 2009; Accepted: February 19, 2010.

\section{Introduction}

Coffee is an important crop in several countries. Of all the species, Coffea arabica L. is the most widely grown, due both to the low caffeine content and the smooth final beverage. This species accounts for almost the entire production of Latin American countries (Orozco-Castillo et al., 1994).

Traditionally, morphological and biochemical characteristics have been used to characterize varieties. Although these markers are still important, they are somewhat limited, through the need for physical space for evaluation, the effect of environmental conditions on character expression, and the time required for making a full description, as several characters need to be evaluated during the entire growth period of the plant. For coffee trees, the latter limitation is extremely relevant, through being a perennial crop requiring three-years-growth until full maturity (Mendes and Guimarães, 1998). It takes at least fifteen years to obtain a new variety.

In 2001, C. arabica was included on the Brazilian roll of species from which varieties can be protected, without, however, indicating stable and homogeneous markers re-

Send correspondence to Elisa Serra Negra Vieira. Cooperativa Central de Pesquisa Agrícola, BR 467, km 98, Caixa Postal 301, 85813-450 Cascavel, PR, Brazil. E-mail: esnegra@coodetec. com.br. quired for the effective enforcement of protective measures. In the past, DNA-based markers have been used for studying genetic diversity in many plant species. This type of marker, besides facilitating the analysis of variation present in DNA itself, can also be used for variety identification. In addition, they are environmentally independent, and may be detected in any type of tissue and developmental phase of the plant (Arens et al., 1995; Ferreira and Grattapaglia, 1998). Analysis of C. arabica varieties in Brazil has revealed that the material employed is derived from few ancestral varieties (Typica, Bourbon and Sumatra), which themselves have undergone mutual spontaneous mutations and crossings (Mendes and Guimarães, 1998).

Nuclear DNA variation in coffee has been evaluated by using molecular markers such as RFLP (Lashermes et al., 1999), RAPD (Diniz et al., 2005; Anthony et al., 2002, Silveira et al., 2003), AFLP (Steiger et al., 2002; Anthony et al., 2002) and SSRs (Combes et al., 2000; Anthony et al., 2002; Moncada and McCouth 2004; Maluf et al., 2005; Poncet et al., 2006; Aggarwal et al., 2007; Silvestrini et al., 2007), whereby it has been shown that genetic variation in the genus Coffea is low, especially among cultivated $C$. arabica tetraploid varieties. Chloroplast DNA (cpDNA) non-coding regions have been used as a source of molecular markers in studies concerning the relationships within 
and among species of this genus (Orozco-Castillo et al., 1996; Cros et al., 1998), where only interspecific polymorphism was detected.

Simple sequence repeats (SSR), or microsatellite markers, are very attractive for studies in plant genetics, through their usefulness in evaluating those varieties with a narrow genetic base (Bredemeijer et al., 2002). Furthermore, they can be efficiently analyzed by rapid and simple polymerase chain reactions, besides being co-dominant, highly reproducible and multi-allelic, and capable of being automated (Ferreira and Grattapaglia, 1998).

By using markers developed for C. arabica, Moncada and McCouth (2004) showed the particular value of SSR markers for discriminating closely related commercial varieties of coffee. Maluf et al. (2005) and Silvestrini et al. (2007) confirmed the low genetic diversity in coffee, mainly in tetraploid varieties, although none were related to the varieties under study.

The number of microsatellite markers currently available for coffee remains limited. To date, only 224 genomic SSR markers for species of the Coffea genus have been de- scribed (Hendre et al., 2008). Coffea arabica is the most important, and there is an urgent need for additional microsatellite makers for facilitating the identification of closely related varieties. Thus, the aim was to develop and characterize additional microsatellite markers for $C$. arabica, and evaluate their use in identifying varieties of commercial interest in Brazil.

\section{Material and Methods}

\section{Plant material and DNA isolation}

A set of 19 Coffea arabica varieties was selected, these representing all the major varieties grown in Brazil (Table 1). The DNA of each genotype was extracted from ground seeds. Six interspecific hybrids of C. arabica, $C$. liberica and $C$. canephora from the Centro de Investigação das Ferrugens do Cafeeiro (CIFC) were included in this work. The DNA of this material was extracted from freeze-dried leaves. For the construction of genomic libraries enriched for microsatellites, DNA was extracted from leaves of variety Catuaí Vermelho IAC-44 (C.arabica). In

Table 1 - Genealogy of the studied coffee varieties.

\begin{tabular}{|c|c|c|c|}
\hline Number & Origin & Name & Background \\
\hline 1 & Brazil & Acaiá Cerrado MG1474 & Selection from Mundo Novo \\
\hline 2 & Brazil & Mundo Novo IAC 376-4 & Sumatra X Bourbon Vermelho \\
\hline 3 & Brazil & Obatã IAC1669-20 & Selection from Sarchimor ${ }^{1}$ \\
\hline 4 & Brazil & Oeiras MG 6851 & Selection from Caturra Vermelho X Hibrido do Timor \\
\hline 5 & Brazil & Ouro Verde IAC H5010-5 & Selection from Catuaí Amarelo and Mundo Novo \\
\hline 6 & Brazil & Rubi MG1192 & BC Catuaí Vermelho X Mundo Novo \\
\hline 7 & Brazil & Topázio MG1190 & BC Catuaí Amarelo X Mundo Novo \\
\hline 8 & Brazil & Bourbon Amarelo IAC J22 & Típica \\
\hline 9 & Brazil & Bourbon Vermelho IAC 662 & Típica \\
\hline 10 & Brazil & Catuaí Amarelo IAC 62 & Selection Mundo Novo X Caturra Amarelo \\
\hline 11 & Brazil & Catuaí Vermelho IAC 99 & Mundo Novo X Caturra Amarelo \\
\hline 12 & Brazil & Catucaí Amarelo 2015/ cova 479 & Icatu Amarelo X Catuaí Vermelho \\
\hline 13 & Brazil & Catucaí Vermelho 2015/cova 476 & Icatu Vermelho X Catuaí Amarelo \\
\hline 14 & Brazil & Caturra Amarelo IAC 476 & Mutant of Bourbon Vermelho \\
\hline 15 & Brazil & Caturra Vermelho IAC 477 & Mutant of Bourbon Vermelho \\
\hline 16 & Brazil & IAPAR 59 & Selection from Sarchimor ${ }^{\mathrm{a}}$ \\
\hline 17 & Brazil & Tupi IAC 1669-33 & Selection from Sarchimor ${ }^{\mathrm{a}}$ \\
\hline 18 & Brazil & Icatu Amarelo IAC 2944 & Bourbon Amarelo X Icatu Vermelho \\
\hline 19 & Brazil & Icatu Vermelho IAC 2945 & Bourbon Vermelho X C. canephora \\
\hline 20 & Portugal & CIFC H147/1 & C. arabica X C. liberica \\
\hline 21 & Portugal & CIFC 34/13 (S353-4/5) & C. arabica X C. liberica \\
\hline 22 & Portugal & CIFC 832/1 & Híbrido do Timor (C. arabica X C. canephora) \\
\hline 23 & Portugal & CIFC 1343/269 & Híbrido do Timor clone (C. arabica X C. canephora) \\
\hline 24 & Portugal & CIFC $110 / 5$ & C. arabica X C. Arabica \\
\hline 25 & Portugal & CIFC H539/8 & C. arabica X C. Canephora \\
\hline
\end{tabular}

${ }^{1}$ Sarchimor $=$ Villa Sarchi X Híbrido do Timor $(=$ C. arabica X C. canephora $)$. 
all cases the DNA extraction was carried out using the DNeasy Plant Mini Kit (Qiagen), according to manufacturer's instructions.

\section{SSR sequences from public databases and primer design}

Coffee microsatellite sequences were extracted from the NCBI database. Those containing di-nucleotide $(n>10)$ or tri-nucleotide $(n>6)$ repeats were selected for primer design. PCR primers flanking the repeat sequence were designed using the primer select module of the DNAstar Lasergene package. Six SSRs for C. arabica described by Combes et al. (2000) and 13 cpDNA SSRs (Taberlet et al., 1991; Orozco-Castillo et al., 1996) were also tested.

\section{Microsatellite isolation}

Additional microsatellites were isolated from enriched small-insert genomic libraries constructed according to Van de Wiel et al. (1999), with a minor modification. DNA of the Catuaí Vermelho IAC-44 variety was digested with $A l u \mathrm{I}, R s a \mathrm{I}, M b o \mathrm{I}$ or TaqI enzymes instead of being sonicated. After digestion, the DNA fragments were hybridized to filters containing the following synthetic oligonucleotides: $(\mathrm{TCT})_{10},(\mathrm{TGT})_{9},(\mathrm{GAG})_{8},(\mathrm{GTG})_{8},(\mathrm{TGA})_{9}$, $(\mathrm{AGT})_{10},(\mathrm{CGT})_{8},(\mathrm{GCT})_{8},(\mathrm{CT})_{12}$ and $(\mathrm{GT})_{12}$. Filters, on being washed with $0.5 \times$ SSC $1 \%$ SDS (low stringency wash) and $0.2 \times S S C 1 \%$ SDS (high stringency wash), gave rise to two genomic libraries.

\section{Nomenclature}

The newly developed markers were named according to the nomenclature proposed by Hendre et al. (2008) for $C$. canephora SSR markers. Each marker was identified by the suffix CarM, indicating C. arabica microsatellite marker, followed by a number.

\section{Microsatellite analysis}

Microsatellites were amplified by PCR in a $20 \mu \mathrm{L}$ reaction volume, containing $10 \mathrm{mM}$ of Tris- $\mathrm{HCl} \mathrm{pH} 9.0$, $20 \mathrm{mM}$ of $\left(\mathrm{NH}_{4}\right)_{2} \mathrm{SO}_{4}, 0.01 \%$ Tween $20,1.5 \mathrm{mM} \mathrm{MgCl}_{2}$, $0.1 \mathrm{mM}$ of each dNTP, 4 pmol of each primer, 0.2 units of Goldstar Taq DNA polymerase (Eurogentec, Maastricht, The Netherlands), and $16 \mathrm{ng}$ of genomic DNA. The amplifications were performed in a PTC-200 MJ Research Thermal Cycler, programmed for one step at $94{ }^{\circ} \mathrm{C}$ for $3 \mathrm{~min}$, followed by 30 cycles $\left(30 \mathrm{~s}\right.$ at $94{ }^{\circ} \mathrm{C}, 30 \mathrm{~s}$ at the annealing temperature determined for each primer pair, and $45 \mathrm{~s}$ at $72{ }^{\circ} \mathrm{C}$ ), and a final extension at $72^{\circ} \mathrm{C}$ for $3 \mathrm{~min}$. All primers were synthesized by Eurogentec (Maastricht, The Netherlands) (Table S1).

The PCR products were separated on $6 \%$ polyacrylamide gels, by using a Sequi-Gen Sequencing Cell (Bio$\mathrm{Rad}$ ) apparatus at $110 \mathrm{~W}$ for $1-3 \mathrm{~h}$ in $1 \mathrm{x}$ TBE buffer. After electrophoresis, the products were visualized through silver staining as described by Van de Wiel et al. (1999), and the patterns analyzed for the presence of polymorphism and the quality of the banding pattern, according to Arens et al. (1995).

\section{Data analysis}

For polymorphic microsatellite loci, the number of alleles per locus and allelic phenotypes were counted. Considering that $C$. arabica is a tetraploid species, assessing the actual genotype itself based on band intensity is unreliable. Therefore, banding patterns were observed for each polymorphic locus and recorded as allelic phenotypes (Becher et al., 2000). In order to quantify the discrimination power of the microsatellite markers, the number of effective alleles (ne) for each marker was calculated according to the formula (Hartl and Clark, 1997): $n e=1 / \Sigma(E / F)^{2}$, where $E$ is the total number of genotypes with each allele of locus $i$, and $\mathrm{F}$ is the total number of alleles of the locus $i$ in all genotypes.

A presence/absence (1/0) allele matrix was built, and Jaccard similarity was calculated by using the NTSYS (version 2.1) computer program. UPGMA dendrogram was calculated using the SHAN algorithm of the NTSYS package. Bootstrapping was applied to evaluate the degree of association between the genetic similarity matrix and dendrogram, using the BOOD software version 3.0 (Coelho, 2001). Pearson correlationship was calculated using the GENES software Windows version (Cruz, 2001) to indicate the extent to which the clustering of genotypes demonstrated in the dendogram accurately represents the estimates of genetic similarity.

\section{Results}

\section{Microsatellite enrichment from C. arabica}

An overview of the results obtained with microsatellite enrichment procedures is given in Table 2. An arbitrary number of positive clones were sequenced. Of the 135 recombinant clones obtained from the first enrichment (low stringency library), 110 were sequenced, with $41 \%$ (45) containing a microsatellite sequence, 2 of which redundant. Twenty microsatellite sequences had perfect repeats, 22 had imperfect repeats and three were compound repeats. Flanking regions in eighteen inserts were large enough for primer design. From the 397 recombinant clones characterized in the second enrichment (high stringency library), 192 were sequenced, with $46 \%$ (89) containing microsatellite sequences, 14 of which redundant. For this set, 51 microsatellite sequences were perfect repeats and 29 imperfect and nine were compound repeats. Flanking regions in 35 inserts were suitable for primer design.

In total, 53 primer pairs could be developed, 23 for di-, 24 for tri-, 3 for tetra-, 2 for penta- and 1 for compound-nucleotide repeats. The latter two were found only in the first enriched library. The sequences of all markers obtained are shown in Table S1. Compound microsatellite 
Table 2 - Results from microsatellite cloning and sequencing of two enriched libraries (EL) of $C$. arabica. Two elution conditions were used: 1) low-stringency $(0.5 x S S C)$ and 2$)$ high-stringency $(0.2 x S S C)$. Positive clone indicates the number of clones hybridizing to a labeled oligo probe mixture. SSR indicates the number of clones containing a microsatellite. Designed primers indicate the number of clones on the basis of which primers could be designed for amplification of the microsatellite.

\begin{tabular}{ccccccc}
\hline EL & Screened clones & Positive clones & Sequenced clones & SSR & Primers designed & Polymorphic markers \\
\hline 1 & 3572 & 135 & 110 & 45 & 18 & 2 \\
2 & 3840 & 397 & 192 & 89 & 35 & 5 \\
\hline
\end{tabular}

sequences consisting of CCA/TCA and TGA/GAA repeats were found in both libraries, whereas clones containing microsatellite sequences which were not specifically searched for, as GGA, were found in the first. GT and TGA were the most common di- and tri-nucleotide motifs encountered (results not shown). All 53 primer pairs produced a clear PCR fragment.

\section{Markers from public database sequences and literature}

The screening of a public (NCBI) database for microsatellite sequences resulted in 56 accessions which met the set criteria (more than 6 repeat units per trinucleotide repeat and 10 repeat units per di-nucleotide). Some of these sequences had already been used for marker development. Nevertheless, as primer design was undertaken independently, there are differences in the primers used to amplify SSR markers in our study and theirs (Coulibaly et al., 2003; Poncet et al., 2006). An additional 6 primer pairs were available from literature (Combes et $a l ., 2000)$. These sequences are also incorporated in Table S1. Beside the nuclear DNA markers, $13 \mathrm{cpDNA}$ primers were tested (Taberlet et al., 1991; Orozco-Castillo et al., 1996).

\section{Marker characterization and allelic variation}

A total of 127 primer pairs were tested for pattern quality and degree of polymorphism using a set of 19 coffee-varieties and 6 inter-specific hybrids. 125 primers amplified the expected DNA fragments, although only 22 were polymorphic. Most markers contained a GT repeat. All polymorphic markers gave a pattern quality of 1 or 2
(Arens et al., 1995) and could be scored unambiguously. An example of the molecular pattern obtained with the CarM092 marker is shown in Figure 1. A total of 55 alleles were detected using the 22 polymorphic SSR loci, the number of alleles per locus ranging from 1 to 7 , an average of 2.5 alleles per locus (Table 3 ).

\section{Variety identification}

The 22 polymorphic SSR markers were used to group the set of varieties and inter-specific hybrids. The UPGMA dendrogram revealed that most of the Brazilian varieties were placed in a group with high bootstrap value $(81.7 \%)$, thereby indicating reliable clustering (Figure 2$)$. The interspecific hybrids and two Brazilian varieties (Tupi and Icatu Vermelho) were placed in groups with bootstrap values below 50\%. Pearson correlation was 0.958 , thus indicating that the observed clustering of varieties in the dendrogram accurately represented the estimates of genetic similarity.

The allelic profiles of all the varieties used in this study can be seen in Table S2. As regards Brazilian material, variety-specific alleles were detected with the markers CarM101, CarM051 and CarM052 for the varieties Bourbon Vermelho, Icatu Amarelo and Vermelho.

The loci CarM068, CarM086, CarM002, ccmp3, ccmp10 and NTCP8 amplified only in interspecific hybrids.

The CarM051 locus was the most discriminating, with six allelic phenotypes and 3.4 effective alleles (Table 3). Although for CarM092 the effective alleles count was low, with only four allelic phenotypes, it was, together with CarM101, CarM051 and CarM052, one of the more discriminating markers for Brazilian varieties.

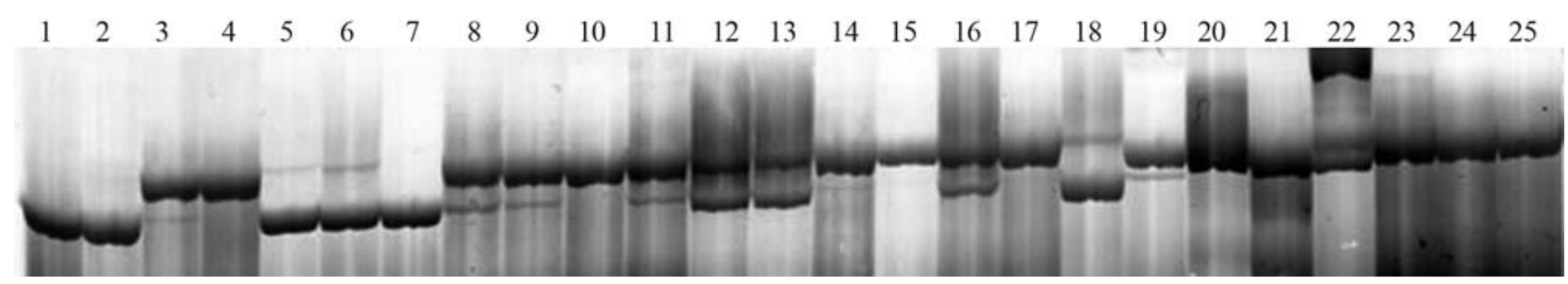

Figure 1 - Molecular pattern obtained with the marker CarM092 (1: Acaiá Cerrado MG1474; 2:Mundo Novo IAC 376-4; 3:Obatã IAC 1669-20; 4: Oeiras MG6851; 5: Ouro Verde IAC H5010-5; 6: Rubi MG1 192; 7: Topázio MG1190; 8: Bourbon Amarelo IAC J22; 9: Bourbon Vermelho IAC 662; 10: Catuaí Amarelo IAC 62; 11: Catuaí Vermelho IAC 99; 12:Catucaí Amarelo 2015/cova479; 13: Catucaí Vermelho 2015/cova476; 14: Caturra Amarelo IAC 476; 15: Caturra Vermelho IAC 477; 16: IAPAR 59; 17: Tupi IAC 1669-33; 18: Icatu Amarelo IAC2944; 19: Icatu Vermelho IAC 2945; 20: CIFC H147/1; 21 : CIFC 34/13(S353-4/5); 22: CIFC 832/1; 23: CIFC1343/269; 24: CIFC 110/5; 25: CIFC H539/8. 
Table 3 - Number of alleles per locus, number of effective alleles (ne) and number of allelic phenotypes from the 22 polymorphic microsatellite markers.

\begin{tabular}{|c|c|c|c|}
\hline SSR marker & $\begin{array}{l}\text { N. of alleles per } \\
\text { locus }\end{array}$ & $\begin{array}{l}\text { N. of effective } \\
\text { alleles (ne) }\end{array}$ & $\begin{array}{l}\text { N. of allelic } \\
\text { phenotype }\end{array}$ \\
\hline $\mathrm{M} 20^{1}$ & 3 & 1.3 & 4 \\
\hline M24 & 4 & 1.9 & 5 \\
\hline CarM065 & 1 & 1 & 1 \\
\hline CarM070 & 1 & 1 & 1 \\
\hline CarM069 & 2 & 1.1 & 2 \\
\hline CarM068 & 1 & 1 & 1 \\
\hline CarM086 ${ }^{3}$ & 1 & 1 & 1 \\
\hline CarM092 & 3 & 1.9 & 4 \\
\hline CarM096 & 3 & 1.8 & 2 \\
\hline CarM101 & 7 & 3.9 & 4 \\
\hline CarM105 & 2 & 1.4 & 3 \\
\hline CarM001 ${ }^{4}$ & 1 & 1 & 1 \\
\hline CarM002 & 1 & 1 & 1 \\
\hline CarM048 & 5 & 1.8 & 6 \\
\hline CarM049 & 2 & 1.2 & 3 \\
\hline CarM050 & 2 & 1.5 & 2 \\
\hline CarM051 & 5 & 3.4 & 6 \\
\hline CarM052 & 7 & 1.8 & 7 \\
\hline $\mathrm{Ccmp}^{6}{ }^{6}$ & 1 & 1 & 1 \\
\hline Ccmp6 & 2 & 1.2 & 2 \\
\hline Ccmp10 & 1 & 1 & 1 \\
\hline NTCP8 & 1 & 1 & 1 \\
\hline \multicolumn{2}{|c|}{ Total number of alleles } & 55 & \\
\hline \multicolumn{2}{|c|}{ Average alleles/locus } & 2.5 & \\
\hline
\end{tabular}

${ }^{1}$ Primer sequences published by Combes et al. (2000), ${ }^{2}$ Primers developed from clone sequences published by Rovelli et al. (2000) in the NCBI database; ${ }^{3}$ Primers developed from clone sequences published in the NCBI database; ${ }^{4}$ Primers obtained in the first genomic library; ${ }^{5}$ Primers obtained in the second genomic library; ${ }^{6} \mathrm{Chloroplast} \mathrm{markers.}$

\section{Discussion}

\section{Enriched libraries}

Enrichment based on the hybridization of genomic DNA fragments to filters containing synthetic oligonucleotide repeats, has been shown to be an efficient way of microsatellite retrieval in several species like tomato, lettuce, roses and C. canephora (Vosman and Arens, 1997; Van de Wiel et al., 1999; Esselink et al., 2003; Hendre et al., 2008). Results presented in this paper indicated efficacy also for C. arabica.

In terms of efficiency, the second library (high stringency filter washing) generated a higher frequency of clones containing microsatellites, which, besides being longer, consisted of a higher percentage of perfect repeats. Most of the di-nucleotide microsatellite repeats were of the GT mo-

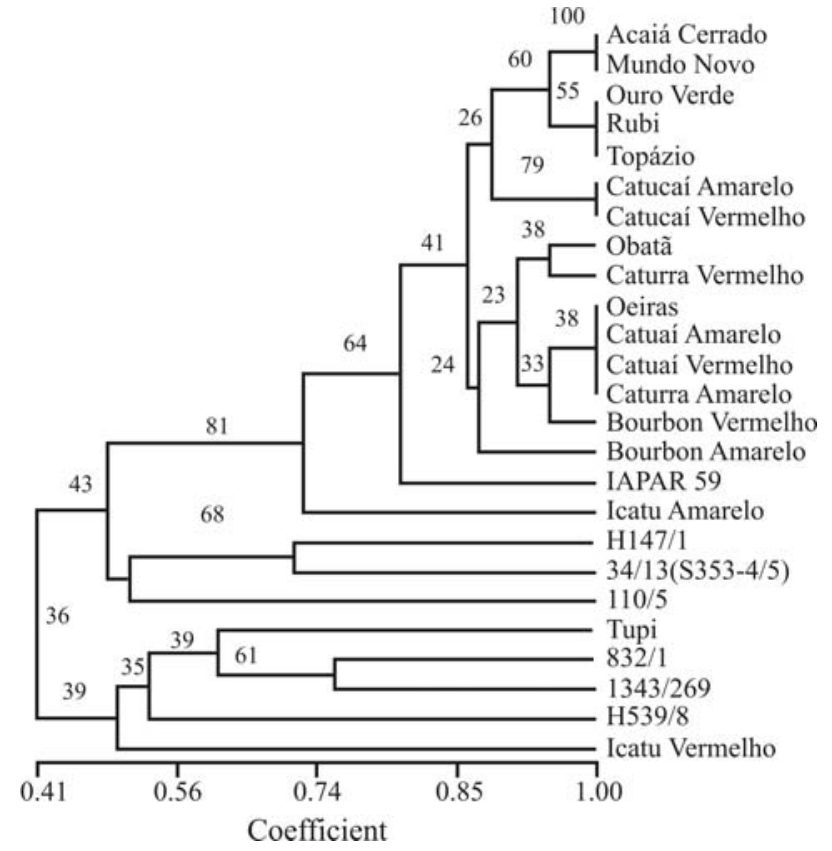

Figure 2 - UPGMA dendrogram obtained using the Jaccard similarity of 19 coffee varieties and 6 interspecific hybrids, with data from 22 polymorphic microsatellite loci (Bootstrap values are in percentages).

tif, which is in agreement with previous microsatellite retrieval efforts in coffee (Vascotto et al., 1999), and with the C. arabica microsatellite sequences present in the NCBI database. In contrast, Ruas et al. (2003) showed that the GA-nucleotide motif, combined with other di, tri and tetranucleotide motifs, produced a high number of DNA fragments, thereby inferring a high frequency of poly GA microsatellite motifs in the coffee genome. It is well known that di-nucleotide repeats are very common in plants (Morgante and Olivieri, 1993). In C. canephora, the most common was di-nucleotide repeats (AT and AG) (Hendre et al., 2008), which is in agreement with our results. The TGA motif was the most common among the tri-nucleotides, whereas in C. canephora, this was AGC (Hendre et al. 2008). Clones containing the TGA motif were also found by Vascotto et al. (1999) in coffee and other species, such as tomatoes and roses (Esselink et al., 2003; He et al., 2003). In Arabidopsis thaliana (Depeiges et al., 1995), sugarcane (Cordeiro et al., 2000) and black poplar (Van der Schoot et al., 2000), the frequency of this motif was lower. In general SSR markers developed for Coffea sp. are mainly comprised of di and tri-nucleotide repeats (Poncet et al., 2006; Aggarwal et al., 2007).

\section{Allele variation}

In the set of coffee varieties and interspecific hybrids, only 22 (17\%) out of the 127 markers tested were polymorphic, thereby clearly revealing the narrow genetic base of coffee. There was little diversity among the material tested, especially among the Brazilian varieties. The number of alleles per locus ranged from 1 to 7 , which is in agreement 
with previous studies (Vascotto et al., 1999; Anthony et al., 2002; Moncada and McCouth 2004; Aggarwal et al., 2007; Hendre et al., 2008).

Moncada and McCouch (2004) used a set of 34 SSR markers to distinguish closely related commercial varieties of $C$. arabica, thereby confirming the need for working with SSR marker sets, in the case of crops with a narrow genetic base.

On considering the low level of polymorphism detected with isolated microsatellites, an attractive strategy could be to first try selecting SSRs with a high chance of being polymorphic. Recently, a software tool for identifying such SSRs in EST sequences was developed (Tang et al., 2008). With more than 55,000 ESTs in the database (NCBI, December 2008), it was possible to identify several promising SSRs based on coding regions (Poncet et al., 2006; Aggarwal et al., 2007).

\section{Variety identification}

As already mentioned, C. arabica varieties are highly similar to each other. This high genetic similarity is possibly a consequence of the self-pollinating nature of $C$. arabica, as well as the breeding strategies used for coffee (Lashermes et al., 1999; Combes et al., 2000; Anthony et al., 2002; Steiger et al., 2002; Ruas et al., 2003; Moncada and McConch 2004; Maluf et al., 2005).

The interspecific hybrids clustered far from most of the Brazilian varieties probably because of the presence of C. canephora and $C$. liberica in the genealogy of these genotypes. This could be confirmed by using chloroplast markers, which detect only inter-specific variation (Table S2). The same was shown by Orozco-Castillo et al. (1996) in a study of taxonomic relationships within the genus Coffea, when using chloroplast DNA markers. Taberlet et al. (1991) also demonstrated that the sequence of chloroplast DNA intergenic spacers can be used for phylogenetic studies of closely related species. The removal of chloroplast data from the analysis did not alter the dendrogram obtained in the present study, thereby showing that the clustering obtained was really based on the presence of other Coffea species. This is also the case for Brazilian coffee variety clustering with interspecific genotypes. The Tupi variety is a hybrid between $C$. arabica and Híbrido do Timor. Icatu Vermelho comes from a cross between C. canephora and Bourbon Vermelho. Even though C. canephora is present in the genealogies of Oeiras, Catucaí Amarelo, Catucaí Vermelho and Obatã, these genotypes were grouped separate from interspecific hybrids. This might be due to differences in the background of the material used, or to the size of $C$. canephora introgressions in the varieties. The clustering of Brazilian varieties is in accordance with genealogical data. The varieties Acaiá Cerrado and Mundo Novo showed $100 \%$ similarity, which can be explained by Acaiá Cerrado being a selection inside Mundo Novo. In spite of the high genetic similarity among varieties, they are pheno- typically different. In Acaiá Cerrado, tree-tops are cylindrical and diameter reduced when compared to Mundo Novo. Maluf et al. (2005) also found these two varieties to be identical. Genetic similarity among Ouro Verde, Rubi and Topázio is most probably due to the latter two having Catuaí as a parent, whereas Ouro Verde is a selection from Catuaí Amarelo. In Ouro Verde and Rubi, fruits are red and in Topázio yellow, whereas the young leaves of Ouro Verde are green and those of Rubi tanned.

The impossibility of separating color mutants, such as Catucaí Amarelo and Vermelho and Catuaí Amarelo and Vermelho, is to be expected, as mutants are usually the result of very few mutations that are difficult to spot with molecular markers (Weising et al., 1995; Vosman and Arens, 1997). No polymorphism caused by mutation was observed with microsatellites in peaches (Testolin et al., 2000), Pelagonium (Becher et al., 2000) and roses (Esselink et al., 2003; Vosman et al., 2004). When a mutation occurs in any of the genes involved in the synthesis of color components, a color-mutant might be generated. In coffee, one gene involved in fruit-color formation is known, and two alleles (Xc and xc) have been identified (Mendes and Guimarães, 1998). Among the commercial arabica varieties, there are other morphological differences, such as plant height, leaf shape and size, leaf-color, branch-angle and stature. However, the differences among varieties at the DNA level are limited, probably due to several commercial arabica varieties originating either from single mutations or few ancestors.

According to the pairwise similarity matrix, genetic similarity was at least 0.860 in Obatã, Caturra Amarelo and Vermelho, Oeiras, Catuaí Amarelo and Vermelho and Bourbon Vermelho. Many of these varieties are known mutants or were obtained from selections or crosses between these varieties, as is shown in Table 1. Similar results have been recorded by many authors. Steiger et al. (2002) and Maluf et al. (2005) also observed high genetic similarity between Caturra and Catuaí. The Obatã variety is a selection from Sarchimor, itself originating from crossing Villa Sarchi with Híbrido do Timor. High genetic similarity was also observed between the varieties Villa Sarchi and Caturra (Anthony et al., 2002). Thus Obatã was clustered with the above mentioned varieties.

The distance between Bourbon Vermelho and Amarelo is probably due to the latter being a natural cross between Bourbon Vermelho and the variety Amarelo de Botucatu (Mendes and Guimarães, 1998; Maluf et al., 2005). Anthony et al. (2002) noted that the M-24 primer was useful for discriminating Bourbon from other varieties. In the present work the same primer amplified an allele that also facilitated the separation of Bourbon Amarelo from all other Brazilian varieties.

Probably through being derived from Sarchimor with C. canephora ancestry, IAPAR 59 remained clustered close to interspecific hybrids. Likewise, the varieties Icatu 
Amarelo, Icatu Vermelho and Tupi, also with C.canephora as a common ancestor, were clustered among interspecific material.

Irrespective of the high genetic similarity, a certain level of polymorphism is still to be found among C. arabica varieties, whereby hybrids with better performances have been obtained in Brazilian breeding programs. Heterosis reached $25 \%$ in hybrids between the varieties IAPAR 59 and Mundo Novo (Diniz et al., 2005). This could be the result of the complementary action of simply a few genes.

The present fingerprint data generated for Brazilian varieties could be used to construct a DNA reference database for the molecular identification of varieties, as previously suggested (Bredemeijer et al., 2002; Aggarwal et al., 2004; Hendre et al., 2008).

\section{Acknowledgments}

The authors wish to thank Martijn van Kaauwen, Yolanda Noordijk and Wendy Van't Westende for technical support, Paul Arens for helpful discussions, the Instituto Agronômico do Paraná (IAPAR), the Universidade Federal de Lavras (UFLA), Epamig and Sjaak van Heusden for providing material, and Antônio Nazareno Guimarães Mendes for providing information on varieties. This research received financial support from CAPES (Coordenação de Aperfeiçoamento de Nível Superior, Brazil).

\section{References}

Aggarwal RK, Rajkumar R, Rajendrakumar P, Hendre PS, Baruah A, Phanindranath R, Annapurna V, Prakash NS, Santaram A, Sreenivarsan CS, et al. (2004) Fingerprint of Indian coffee selections and development of reference DNA polymorphism panels for creating molecular IDs for variety identification. In: Proceedings of $20^{\text {th }}$ International Conference on Coffee Science (ASIC). Bangalore, India, pp 751-755.

Aggarwal RK, Hendre PS, Varshney RK, Bhat PR, Krishnakumar $\mathrm{V}$ and Singh L (2007) Identification, characterization and utilization of EST-derived genic microsatellite markers for genome analyses of coffee and related species. Theor Appl Genet 114:359-372.

Anthony F, Quiros O, Ropart P, Bertrand B and Lashermes P (2002) Detection by simple sequence repeat markers of introgression from Coffea canephora in Coffea arabica varieties. Plant Breed 121:542-544.

Arens P, Bredemeijer G, Smulders M and Vosman B (1995) Identification of tomato varieties using microsatellites. Acta Hort 412:49-57.

Becher SA, Steinmetz K, Weising K, Boury S, Peltier D, Renou JP, Kahl G and Wolff K (2000) Microsatellites for variety identification in Pelargonium. Theor Appl Genet 101:643651.

Bredemeijer GMM, Cooke RJ, Ganal MW, Peeters R, Isaac P, Noordijk Y, Rendell S, Jackson J, Roder MS, Wendehake K, et al. (2002) Construction and testing of microsatellite database containing more than 500 tomato varieties. Theor Appl Genet 105:1019-1026.
Coelho ASG (2001) BOOD - Avaliação de dendrogramas baseada em estimativas de distancias/similaridades genéticas através do procedimento de bootstrap, v. 3.0. Universidade Federal de Goiás, Goiânia.

Combes M, Andrzejewski S, Anthony F, Bertrand B, Rovelli P, Graziosi G and Lashermes P (2000) Characterization of microsatellite loci in Coffea arabica and related coffee species. Mol Ecol 9:1171-1193.

Cordeiro GM, Taylor GO and Henry RJ (2000) Characterization of microsatellite markers from sugarcane (Saccharum $\mathrm{sp}$ ). A highly polyploid species. Plant Sci 155:161-168.

Coulibaly I, Revol B, Noirot M, Poncet V, Lorieux M, Carasco-Lacombe C, Minier J, Dufour M and Hamon P (2003) AFLP and SSR polymorphism in a Coffea interspecific backcross progeny $[(C$ heterocalyx $\times C$. canephora $) \times C$. canephora]. Theor Appl Genet 107:1148-1155.

Cros J, Combes MC and Trouslot P (1998) Phylogenetic analysis of chloroplast DNA variation in Coffea L. Mol Phylogenet Evol 9:109-117.

Cruz CD (2001) Programa GENES. Universidade Federal de Viçosa, Viçosa, 648 pp.

Depeiges A, Golbely C, Lenoir A, Cocherel S, Picard G, Raynal M, Grellet F and Delseny M (1995) Identification of the most represented repeated motif in Arabidopsis thaliana microsatellite loci. Theor Appl Genet 91:160-168.

Diniz LEC, Ruas CF, Carvalho VP, Torres FM, Ruas EA, Santos MO and Sera T (2005) Genetic diversity among 40 coffee varieties accessed by RAPD markers associated with restriction digestion. Arq Biol Tecnol 4:511-521.

Esselink GD, Smulders MJM and Vosman B (2003) Identification of cut rose (Rosa hybrida) and rootstock varieties using robust sequence tagged microsatellite site markers. Theor Appl Genet 106:277-286.

Ferreira ME and Grattapaglia D (1998) Introdução ao Uso de Marcadores Moleculares em Análises Genéticas. 2nd edition. Embrapa-Cenargen, Brasília, 220 pp.

Hartl L and Clark AG (1997) Principles of Population Genetics. 3rd edition. Sinauer Associates Inc, Sunderland, 542 pp.

He C, Poysa V and Yu K (2003) Development and characterization of simple sequence repeat (SSR) markers and their use in determining relationships among Lycopersicon esculentum varieties. Theor Appl Genet 106:363-373.

Hendre PS, Phanindranath R, Annapurna V, Lalremruata A and Aggarwal K (2008) Development of new genomic microsatellite markers from robusta coffee (Coffea canephora Pierre ex A. Froehner) showing broad cross-species transferability and utility in genetic studies. BMC Plant Biol 8:e51.

Lashermes P, Combes MC, Robert J, Trouslot P, D'hont A, Anthony F and Charrier A (1999) Molecular characterization and origin of the Coffea arabica L. genome. Mol Gen Genet 261:259-266.

Maluf MP, Silvestrini M, Ruggiero LMC, Guerreiro-Filho O and Colombo CA (2005) Genetic diversity of cultivated Coffea arabica inbred lines assessed by RAPD, AFLP and SSR marker systems. Sci Agric 62:366-373.

Mendes ANG and Guimarães RJ (1998) Genética e Melhoramento do Cafeeiro. UFLA/FAEPE, Lavras, 99 pp.

Moncada P and McCouch S (2004) Simple sequence repeat diversity in diploid and tetraploid Coffea species. Genome 47:501-509. 
Morgante M and Olivieri AM (1993) PCR-amplified microsatellite markers in plant genetics. Plant J 3:175-182.

Orozco-Castillo C, Chalmers KJ, Waugh R and Powell W (1994) Detection of genetic diversity and selective gene introgression in coffee using RAPD markers. Theor Appl Genet 87:934-940.

Orozco-Castillo C, Chalmers KJ, Powell W and Waugh R (1996) RAPD and organelle specific PCR re-affirms taxonomic relationships within the genus Coffea. Plant Cell Rep 15:337341.

Poncet V, Rondeau M, Tranchant C, Cayrel A, Hamon S, Kochko A and Hamon P (2006) SSR mining in coffee tree EST databases: Potential use of EST-SSRs as markers for the Coffea genus. Mol Genet Genomics 276:436-449.

Rovelli P, Mettulio R, Anthony F, Anzuetto F, Lashermes P and Graziosi G (2000) Microsatellites in Coffea arabica L. In: Sera T, Soccol CR, Pandey A and Roussos S (eds) Coffee Biotechnology and Quality. Kluwer Academic Publishers, Dordrecht, pp 123-133.

Ruas PM, Ruas CF, Pampim L, Carvalho VP, Ruas EA and Sera T (2003) Genetic relationship in Coffea species and parentage determination of interspecific hybrids using ISSR (InterSimple Sequence Repeat) markers. Genet Mol Biol 26:319327.

Silveira SR, Ruas PM, Ruas CF, Sera T, Carvalho VP and Coelho ASG (2003) Assessment of genetic variability within and among coffee progenies and varieties using RAPD markers. Genet Mol Biol 26:329-336.

Silvestrini M, Junqueira MG, Favarin AC, Guerreiro-Filho O, Maluf MP, Silvarolla MB and Colombo CA (2007) Genetic diversity and structure of Ethiopian, Yemen and Brazilian Coffea arabica L. accessions using microsatellite markers. Genet Resour Crop Evol 54:1367-1379.

Steiger DL, Nagai C, Moore PH, Morden CW, Osggod FV and Ming R (2002) AFLP analysis of genetic diversity within and among Coffea arabica varieties. Theor Appl Genet 105:209-215.

Taberlet P, Ludovic G, Pantou G and Bouvet J (1991) Universal primers for amplification of three non-coding regions of chloroplast DNA. Plant Mol Biol 17:1105-1109.

Tang J, Baldwin S, Jacobs J, Van der Linden GC,Voorrips RE, Leunissen JAM, Van Eck HJ and Vosman B (2008). Large- scale identification of polymorphic microsatellites using an in silico approach. BMC Bioinformatics 9:374.

Testolin R, Marrazzo T, Cipriani G, Quarta R, Verde I, Dettori MT, Pancaldi M and Sansavini S (2000) Microsatellite DNA in peach (Prunus persica L. Batsch) and its use in fingerprinting and testing the genetic origin of varieties. Genome 43:512-520.

Van de Wiel C, Arens P and Vosman B (1999) Microsatellite retrieval in lettuce (Lactuca sativa L.). Genome 42:139-149.

Van der Schoot J, Pospíkova M, Vosman B and Smulders MJM (2000) Development and characterization of microsatellite markers in black popular (Populus nigra L.) Theor Appl Genet 101:317-322.

Vascotto F, Degli Ivanissevich S, Rovelli P, Anthony R, Anzueto F, Lashermes P and Graziosi G (1999) Microsatellite in Coffea arabica: Construction and selection of two genomic libraries. In: Proceedings of the International Seminar on Biotechnology in the Coffee Agroindustry. IAPAR/IRD, Londrina, pp 125-128.

Vosman B and Arens P (1997) Molecular characterization of GATA/GACA microsatellite repeats in tomato. Genome 40:25-33.

Vosman B, Visser D, Voort JR, Smulders MJM and Eeuwijk F (2004) Detection of mutants and the establishment of essential derivation among rose varieties using AFLP. Theor Appl Genet 109:1718-1725.

Weising K, Nybom H, Wolff K and Meyer W (1995) DNA Fingerprint in Plants and Fungi. CRC Press, Boca Raton, $322 \mathrm{pp}$.

\section{Supplementary Material}

The following online material is available for this article Table S1 - Sequences of the developed primers.

Table S2 - Allelic profiles of the 19 coffee varieties and 6 interspecific hybrids obtained with polymorphic markers.

This material is made available as part of the online article from http://www.scielo.br.gmb.

Associate Editor: Everaldo Gonçalves de Barros

License information: This is an open-access article distributed under the terms of the Creative Commons Attribution License, which permits unrestricted use, distribution, and reproduction in any medium, provided the original work is properly cited. 
Table S1 - SSR loci tested from genomic DNA.

\begin{tabular}{|c|c|c|c|c|c|}
\hline SSR marker & $\begin{array}{l}\text { Accession number } \\
\text { (NCBI) }\end{array}$ & Repeat motif & Primer sequence $\left(5^{\prime}-3^{\prime}\right)$ & $\operatorname{AT}\left({ }^{\circ} \mathrm{C}\right)$ & $\begin{array}{c}\text { Allele size } \\
\text { (C. arabica L.) }\end{array}$ \\
\hline CarM001 ${ }^{1}$ & - & $(\mathrm{GT})_{10}$ & $\begin{array}{l}\text { F: GTCATTTATTTTTCCGGTCATCCAT } \\
\text { R: AGCCCTCGTTCTGCCCACCAAAAGT }\end{array}$ & 53 & $150-250$ \\
\hline CarM002 & - & $(\mathrm{CTT})_{8}(\mathrm{TA})_{10}$ & $\begin{array}{l}\text { F: CGGGAGACGGTGATTTT } \\
\text { R: TATGGGTATTGTTTTGTTTTTA }\end{array}$ & 53 & $150-250$ \\
\hline CarM003 & - & $(\mathrm{TCA})_{6}$ & $\begin{array}{l}\text { F: CTCGAAAGTGAAATACAGAACCAA } \\
\text { R: TGTAGAAGTCAAAATCAGGAACG }\end{array}$ & 50 & $150-200$ \\
\hline CarM004 & - & $(\mathrm{GT})_{10}$ & $\begin{array}{l}\text { F: TAGAGGTTGCCGAGTGGATAGGTGT } \\
\text { R: AAACGGTAGGAGTGGAAGATTGAGC }\end{array}$ & 50 & $150-260$ \\
\hline CarM005 & - & $(\mathrm{GT})_{10}$ & $\begin{array}{l}\text { F: GGGACCCACAAGTGCGAAAAGT } \\
\text { R: TCTAATGAGGGCTGGCTATGA }\end{array}$ & 52 & $180-290$ \\
\hline CarM006 & - & $(\mathrm{GAAAA})_{3}$ & $\begin{array}{l}\text { F: GTTGCCGAGTGGATAGGTGTGAGAG } \\
\text { R: AAACGGTAGGAGTGGAAGATTGAGC }\end{array}$ & 53 & $150-260$ \\
\hline CarM007 & - & $(\mathrm{GAAAA})_{3}$ & $\begin{array}{l}\text { F: CTCATAGCCAGCCCTCATT } \\
\text { R: TCCCAACTTACCTTAGAAACA }\end{array}$ & 50 & $150-210$ \\
\hline CarM008 & - & $(\mathrm{ACTC})_{4}$ & $\begin{array}{l}\text { F: AGGAGCTTGAAGAATGTTGTGAC } \\
\text { R: AGGGGGTATGAGCGAGGGCGTTAGA }\end{array}$ & 54 & $150-280$ \\
\hline CarM009 & - & $(\mathrm{GA})_{19}$ & $\begin{array}{l}\text { F: CGAGCTGCCAAAAACACAAG } \\
\text { R: AAGCAGCCGGGAAGAGGAGCAT }\end{array}$ & 54 & $150-240$ \\
\hline CarM010 & - & $(\mathrm{GT})_{8}$ & $\begin{array}{l}\text { F: TTGGAAAATAAGCTTGGGAAACT } \\
\text { R: TAGCAAAATGGGCAGGAATAATAC }\end{array}$ & 51 & $150-235$ \\
\hline CarM011 & - & $(\mathrm{GAA})_{5}$ & $\begin{array}{l}\text { F: TGCCCCATGAAGAGGAT } \\
\text { R: CAGATTGAGAGTGAGTGAACG }\end{array}$ & 51 & $120-180$ \\
\hline CarM012 & - & $(\mathrm{GGA})_{5}$ & $\begin{array}{l}\text { F: GGAGGAGGAGGGGTTCTTTTCTATC } \\
\text { R: GAGCGTTGGGTGGTCTGGAGGTCAT }\end{array}$ & 50 & $150-240$ \\
\hline CarM013 & - & $(\mathrm{TGAA})_{7}$ & $\begin{array}{l}\text { F: CTTGTAGGTTGGTGGAGGTT } \\
\text { R: TCAAATGCAAAAGAAAGCGATAA }\end{array}$ & 53 & $150-200$ \\
\hline CarM014 & - & $(\mathrm{GAAA})_{4}$ & $\begin{array}{l}\text { F: TAGCGCTTATCCTCTTTCAATCAA } \\
\text { R: TCCCGAGTGCCTTCCCGTCTG }\end{array}$ & 58 & $200-250$ \\
\hline CarM015 & - & $(\mathrm{CCT})_{6}$ & $\begin{array}{l}\text { F: TCGACTCGTCCTCCTCATCAGAAGA } \\
\text { R: GTTGGAGGAGCGGGGAGAGCAGT }\end{array}$ & 58 & $180-345$ \\
\hline CarM016 & - & $(\mathrm{TGC})_{12}$ & $\begin{array}{l}\text { F: AACTCACCTGCCCGCTTATTACT } \\
\text { R: AGGAGGAGGGGAGGAGAGGAACTT }\end{array}$ & 58 & $200-250$ \\
\hline CarM017 & - & $(\mathrm{CCT})_{9}$ & $\begin{array}{l}\text { F: CACCGCCAGCTCCATCATCTCC } \\
\text { R: GGTTGCATTTCCCCCAGTTCTTTTC }\end{array}$ & 59 & $200-280$ \\
\hline CarM018 & - & $(\mathrm{GT})_{19}$ & $\begin{array}{l}\text { F: CCCCGATCCCTCTTTTGGTTA } \\
\text { R: GTGTGGGTAGTGGTGTGAGA }\end{array}$ & 51 & $200-270$ \\
\hline CarM019² & - & $(\mathrm{TC})_{19}$ & $\begin{array}{l}\text { F: ACTCAACAACACAAAAACGGAAGAT } \\
\text { R: TGTAACCCAATAAAAAGTGTGC }\end{array}$ & 52 & $200-270$ \\
\hline CarM020 & - & $(\mathrm{TGA})_{8}$ & $\begin{array}{l}\text { F: GC1ACCCCTACCTCTCCTCCTATTAT } \\
\text { R: CGGCGGCGGTGGCATTGA }\end{array}$ & 57 & $200-270$ \\
\hline CarM021 & - & $(\mathrm{TAC})_{9}$ & $\begin{array}{l}\text { F: GCGGCTTCTGCTGCTGCTC } \\
\text { R: TGGTTTGGGGTTTAAGGATTCACAT }\end{array}$ & 53 & $100-140$ \\
\hline CarM022 & - & $(\mathrm{GAA})_{6}$ & $\begin{array}{l}\text { F: AAGAAAAATGTCCCCCAAAAGAAAT } \\
\text { R: TTGTGTCGAGTGATGCGTGTGAAA }\end{array}$ & 50 & $100-135$ \\
\hline CarM023 & - & $(\mathrm{GA})_{10}$ & $\begin{array}{l}\text { F: CAAGCAGCTGCGGCAAGAATCA } \\
\text { R: AAAAGCTGCCAATATCAACGGTCAT }\end{array}$ & 55 & $200-320$ \\
\hline CarM024 & - & $(\mathrm{CA})_{11}$ & $\begin{array}{l}\text { F: TGGTGCCAATGTTTCTCCTATCG } \\
\text { R: TCTTTAAAACTTGTTCCTCCTTCTG }\end{array}$ & 52 & $200-290$ \\
\hline CarM025 & - & $(\mathrm{CAC})_{14}$ & $\begin{array}{l}\text { F: CACACGGATGACTGACTCTT } \\
\text { R: GTGTTGTGTTTCCTCGTATTATGAT }\end{array}$ & 52 & $200-285$ \\
\hline CarM026 & - & $(\mathrm{GA})_{25}$ & $\begin{array}{l}\text { F: CCAGCAATCCTCCCTCCCACCAC } \\
\text { R: TACCGTATGCAGAGACAACAATG }\end{array}$ & 55 & $260-365$ \\
\hline CarM027 & - & $(\mathrm{CA})_{26}$ & $\begin{array}{l}\text { F: ATCAAACCCACTCCTCAGC } \\
\text { R: GTCCCACTATACCTCTCCATTGT }\end{array}$ & 51 & $200-270$ \\
\hline
\end{tabular}




\begin{tabular}{|c|c|c|c|c|c|}
\hline SSR marker & $\begin{array}{l}\text { Accession number } \\
\text { (NCBI) }\end{array}$ & Repeat motif & Primer sequence $\left(5^{\prime}-3^{\prime}\right)$ & $\mathrm{AT}\left({ }^{\circ} \mathrm{C}\right)$ & $\begin{array}{c}\text { Allele size } \\
\text { (C. arabica L.) }\end{array}$ \\
\hline CarM028 & - & $(\mathrm{CAG})_{8}$ & $\begin{array}{l}\text { F: AGCAGCTGCAGCCACAACA } \\
\text { R: GAGTAAGAGCCCCAGAGCGTAACCT }\end{array}$ & 56 & $200-290$ \\
\hline CarM029 & - & $(\mathrm{CA})_{10}$ & $\begin{array}{l}\text { F: АТTTTCCTTATCCACCAACAACCAT } \\
\text { R: TATTTCTCССССТTTCССТCTATCC }\end{array}$ & 54 & $100-175$ \\
\hline CarM030 & - & $(\mathrm{CTT})_{8}$ & $\begin{array}{l}\text { F: ATATAGCAACGGGTGTAGAAAATGT } \\
\text { R: CACCGATGATGAAGATGAGAAG }\end{array}$ & 54 & $100-180$ \\
\hline CarM031 & - & $(\mathrm{TCA})_{25}$ & $\begin{array}{l}\text { F: CCCCGCCACCCCCAAGATT } \\
\text { R: CTGCAGAAGATGAGGATTTAT }\end{array}$ & 53 & $250-330$ \\
\hline CarM032 & - & $(\mathrm{TGG})_{6}$ & $\begin{array}{l}\text { F: ATCCCTCCACGGCAACCCAAAATA } \\
\text { R: ATCCGCAGCCCTCACCATCCA }\end{array}$ & 57 & $200-290$ \\
\hline CarM033 & - & $(\mathrm{CCA})_{14}$ & $\begin{array}{l}\text { F: AGCCAAACACGCCACTC } \\
\text { R: GGATGACCAACCAACAAATAC }\end{array}$ & 53 & $200-265$ \\
\hline CarM034 & - & $(\mathrm{TGC})_{12}$ & $\begin{array}{l}\text { F: GATGTGGAGGAGGCTGCTGCTAA } \\
\text { R: TAGGGCGCCATCTGGTAGGGTTGT }\end{array}$ & 60 & $200-270$ \\
\hline CarM035 & - & $(\mathrm{CAC})_{6}$ & $\begin{array}{l}\text { F: CCTGTATATTCTCCACCATCATCAT } \\
\text { R: TGGACATTTAAATAAGACAGAGTG }\end{array}$ & 54 & $150-185$ \\
\hline CarM036 & - & $(\mathrm{GCA})_{6}$ & $\begin{array}{l}\text { F: GCAGCAACAACAGCAGACACAGAA } \\
\text { R: TGGGAGGTTTGAATTTTGAGTTGGT }\end{array}$ & 55 & $150-190$ \\
\hline CarM037 & - & $(\mathrm{TCA})_{26}$ & $\begin{array}{l}\text { F: CACTTAACGCCGCAATGACAA } \\
\text { R: CAGAGATGATGGCAATAAACAGACA }\end{array}$ & 53 & $150-210$ \\
\hline CarM038 & - & $(\mathrm{TGC})_{10}$ & $\begin{array}{l}\text { F: GCTGAAATTCCTGCTCCACCAACTC } \\
\text { R: AACCTTCACCCCСТCCAATCTTTCA }\end{array}$ & 58 & $150-220$ \\
\hline CarM039 & - & $(\mathrm{TCC})_{7}$ & $\begin{array}{l}\text { F: CGTAGCGGTGGTGGTCGTTTGAT } \\
\text { R: AGTAGTGCACCATGATGAGGAGGAT }\end{array}$ & 55 & $200-250$ \\
\hline CarM040 & - & $(\mathrm{TGC})_{17}$ & $\begin{array}{l}\text { F: ATTCTGAGCCAAGTTGCCCATTCCT } \\
\text { R: AAACCTTCACCCCTCCAACTTCAGA }\end{array}$ & 58 & $200-260$ \\
\hline CarM041 & - & $(\mathrm{TAC})_{7}$ & $\begin{array}{l}\text { F: TCGGCGGTGATGGAAGTGG } \\
\text { R: TTGAGGGCTAAAGATGTCGTGAGTC }\end{array}$ & 54 & $200-240$ \\
\hline CarM042 & - & $(\mathrm{GA})_{35}$ & $\begin{array}{l}\text { F: CCATTTCCTTCTCCATCTTGCTCTT } \\
\text { R: GATGGTGTCCCTTCTCCCTTGGTC }\end{array}$ & 56 & $150-240$ \\
\hline CarM043 & - & $(\mathrm{TGC})_{10}$ & $\begin{array}{l}\text { F: CTGGTTGTGTTGAATATTTGTAGCA } \\
\text { R: AACCAGTAATTCAGCAGCAGTCTCA }\end{array}$ & 56 & $150-215$ \\
\hline CarM044 & - & $(\mathrm{GT})_{18}$ & $\begin{array}{l}\text { F: TAACACTACTCTCGCCTTCTTCC } \\
\text { R: GCCGTAGCGCCCCCTCCATT }\end{array}$ & 52 & $150-210$ \\
\hline CarM045 & - & $(\mathrm{CT})_{34}$ & $\begin{array}{l}\text { F: AAGCCCTTTCATTTATCCTCGTTAC } \\
\text { R: AGCTGCCCGTCCGTCTTTT }\end{array}$ & 53 & $200-240$ \\
\hline CarM046 & - & $(\mathrm{CA})_{40}$ & $\begin{array}{l}\text { F: GTCCTCAGTCAATACCCAAAAGT } \\
\text { R: TGCCCAGCTCTCGCCAGGAC }\end{array}$ & 55 & $200-250$ \\
\hline CarM047 & - & $(\mathrm{CT})_{23}$ & $\begin{array}{l}\text { F: CAACTGTCGCGCCCCACTTT } \\
\text { R: GGCCTTTCATCGTTTTCACTTTCAC }\end{array}$ & 53 & $100-150$ \\
\hline CarM048 & - & $(\mathrm{GA})_{24}$ & $\begin{array}{l}\text { F: CCAGCAATCCTCCCTCCCACCAC } \\
\text { R: TACCGTATGCAGAGACAACAATG }\end{array}$ & 56 & $280-310$ \\
\hline CarM049 & - & $(\mathrm{GA})_{24}$ & $\begin{array}{l}\text { F: ATGGCAAAGCAAAATGTGGGAAGAG } \\
\text { R: CACCTGAAGAAGATGACAAACTAAT }\end{array}$ & 53 & $350-400$ \\
\hline CarM050 & - & $(\mathrm{TC})_{20}$ & $\begin{array}{l}\text { F: ATCCCTCCACGGCAACCCAAAATA } \\
\text { R: ATCCGCAGCCCTCACCATCCA }\end{array}$ & 55 & $150-190$ \\
\hline CarM051 & - & $(\mathrm{CT})_{10}$ & $\begin{array}{l}\text { F: GATGTGGAGGAGGCTGCTGCTGAA } \\
\text { R: TAGGGCGCCATCTGGTAGGGTTGT }\end{array}$ & 56 & $250-300$ \\
\hline CarM052 & - & $(\mathrm{TC})_{12}$ & $\begin{array}{l}\text { F: AGCAGCTGCAGCCACAACA } \\
\text { R: GAGTAAGAGCCCCAGAGCGTAACCT }\end{array}$ & 54 & $250-290$ \\
\hline CarM053 $^{3}$ & AJ308745 & $(\mathrm{GT})_{12}$ & $\begin{array}{l}\text { F: CAAATCCATGTCGGTCACTTA } \\
\text { R: CAGGGCATCTATCTACTTCTCTTT }\end{array}$ & 55 & $100-155$ \\
\hline CarM054 & AJ308746 & $(\mathrm{CT})_{13}$ & $\begin{array}{l}\text { F: AGGCCTTCATCTCAAAAACC } \\
\text { R: ACTGCCCCGTCAAGCCATTT }\end{array}$ & 55 & $150-220$ \\
\hline CarM055 & AJ308754 & $(\mathrm{CA})_{12}$ & $\begin{array}{l}\text { F: TCGGGTACAAGGGGAGTGGATA } \\
\text { R: GCGGGCTACGGGGTTTGT }\end{array}$ & 55 & $100-170$ \\
\hline
\end{tabular}




\begin{tabular}{|c|c|c|c|c|c|}
\hline SSR marker & $\begin{array}{l}\text { Accession number } \\
\text { (NCBI) }\end{array}$ & Repeat motif & Primer sequence $\left(5^{\prime}-3^{\prime}\right)$ & $\mathrm{AT}\left({ }^{\circ} \mathrm{C}\right)$ & $\begin{array}{c}\text { Allele size } \\
\text { (C. arabica L.) }\end{array}$ \\
\hline CarM056 & AJ308781 & $(\mathrm{TG})_{17}$ & $\begin{array}{l}\text { F: TATCAAAACAACGTGGACATCA } \\
\text { R: GAGAGCAGCTTTTTAGAGGACAT }\end{array}$ & 55 & $150-200$ \\
\hline CarM057 & AJ308774 & $(\mathrm{CAC})_{24}$ & $\begin{array}{l}\text { F: TTTTAAAACTGGGGAGATGGAATA } \\
\text { R: AGCGTGCGGGTGTCGGTGTAG }\end{array}$ & 53 & $150-210$ \\
\hline CarM058 & AJ308793 & $(\mathrm{TG})_{38}$ & $\begin{array}{l}\text { F: CTGAGCGCATGGAAGGAGTAGC } \\
\text { R:GACGCAGGTGGTAGAAGAATGAAGA }\end{array}$ & 55 & $150-190$ \\
\hline CarM059 & AJ308796 & $(\mathrm{TG})_{21}$ & $\begin{array}{l}\text { F: TTTTTCTGGGTTTTCTGTGT } \\
\text { R: GCATTCCCAGGGCTTCAAAA }\end{array}$ & 55 & $100-140$ \\
\hline CarM060 & AJ308800 & $(\mathrm{TG})_{14}$ & $\begin{array}{l}\text { F: GTAGCGGCAGTGGGAATAATA } \\
\text { R: CCGTAGGAACCTCATAACTT }\end{array}$ & 55 & $100-150$ \\
\hline CarM061 & AJ308874 & $(\mathrm{TG})_{12}$ & $\begin{array}{l}\text { F: GCTCACTTGGGCTGGATT } \\
\text { R: TATATTTTCGGTACAAGGGAGTG }\end{array}$ & 55 & $100-130$ \\
\hline CarM062 & AJ308747 & $(\mathrm{CA})_{25}$ & $\begin{array}{l}\text { F: ATCTCCCCAACCTCATGTCTCTGT } \\
\text { R: GTGTGCTGGTAGGTGTTGTGT }\end{array}$ & 55 & $160-220$ \\
\hline CarM063 & AJ308783 & $(\mathrm{TG})_{17}$ & $\begin{array}{l}\text { F: ACTTCGTATGGTTGTCTGT } \\
\text { R: AAATGATAGGAGGCACTTGA }\end{array}$ & 55 & $120-150$ \\
\hline CarM064 & AJ308795 & $(\mathrm{CAT})_{7}$ & $\begin{array}{l}\text { F: TTGACCGGGGCAGAAGTTG } \\
\text { R: ATAGTGTCGGTTGTGTTGTTGAATC }\end{array}$ & 55 & $150-200$ \\
\hline CarM065 & AJ308816 & - & $\begin{array}{l}\text { F: ATTGCTTCTGTCATGCTTATTTG } \\
\text { R: TCCCTTAGACTGATTTTGTGAA }\end{array}$ & 52 & $100-170$ \\
\hline CarM066 & AJ308825 & $(\mathrm{TG})_{18}$ & $\begin{array}{l}\text { F: TTGAGCAAAAACCCTATTCCT } \\
\text { R: TAAACCCAAAAAGACCACAAAAA }\end{array}$ & 55 & $100-150$ \\
\hline CarM067 & AJ308843 & $(\mathrm{TG})_{25}$ & $\begin{array}{l}\text { F: GGGCCCGAACTCCAACCA } \\
\text { R: GGCCAAACCGTCGCATTATC }\end{array}$ & 55 & $100-160$ \\
\hline CarM068 & AJ308854 & $(\mathrm{TC})_{24}(\mathrm{TG})_{9}$ & $\begin{array}{l}\text { F: TACTTAAAGGCCCTGAATACAT } \\
\text { R: GAGACACCCACCCATCC }\end{array}$ & 53 & $250-300$ \\
\hline CarM069 & AJ308856 & $(\mathrm{GA})_{7}(\mathrm{GGGA})_{5}(\mathrm{GT})_{8}$ & $\begin{array}{l}\text { F: GGCTGGTTTTCCTTTTCTG } \\
\text { R: ATTTGCTTATTATCCCACATTG }\end{array}$ & 53 & $250-300$ \\
\hline CarM070 & AJ308860 & $(\mathrm{GA})_{6}(\mathrm{GT})_{9}$ & $\begin{array}{l}\text { F: GTTCCATCCACCCTGTCAC } \\
\text { R: CTGGCTAGCTTCTTTCTGGTTT }\end{array}$ & 53 & $200-250$ \\
\hline CarM071 & AJ308885 & $(\mathrm{CA})_{9}$ & $\begin{array}{l}\text { F: TCGGGTACAAGGGGAGTGGA } \\
\text { R: GCTTGGGCTGGATTTGTGCT }\end{array}$ & 55 & $100-120$ \\
\hline CarM072 & AJ308882 & $(\mathrm{TG})_{9}$ & $\begin{array}{l}\text { F: CTGCGCTAGGTGTTCATCCA } \\
\text { R: AGTGCTCCTTCATCCCTTTTG }\end{array}$ & 50 & $150-200$ \\
\hline CarM073 ${ }^{4}$ & AY102422 & $(\mathrm{CA})_{13}$ & $\begin{array}{l}\text { F: CCATTCCTACCCСТCTGTCCCTCTA } \\
\text { R: CCCCCAAAATCCCCCATCACC }\end{array}$ & 50 & $300-390$ \\
\hline CarM074 & AY102423 & $(\mathrm{TG})_{14}$ & $\begin{array}{l}\text { F: AAGAGCAACCACATTTATTA } \\
\text { R: GCCCCTTTGTTTCCCATTCT }\end{array}$ & 50 & $250-300$ \\
\hline CarM075 & AY102425 & $(\mathrm{AC})_{13}$ & $\begin{array}{l}\text { F: AAAAGCCACCACAGGAAGTT } \\
\text { R: TTAGAGAAGGGAGTGAAAGACATC }\end{array}$ & 46 & $100-160$ \\
\hline CarM076 & AY102426 & $(\mathrm{TG})_{24}$ & $\begin{array}{l}\text { F: TCTATCCTCTATGACGAAACACTG } \\
\text { R: CCTAGGGGGCAAAAAGAT }\end{array}$ & 50 & $100-150$ \\
\hline CarM077 & AY102427 & $(\mathrm{CA})_{11}$ & $\begin{array}{l}\text { F: TGCTTGTCAATATGCCTTTTTCT } \\
\text { R: CCGCAATGACTCCTAACCTAAC }\end{array}$ & 46 & $130-150$ \\
\hline CarM078 & AY102428 & $(\mathrm{GA})_{30}$ & $\begin{array}{l}\text { F: AACCACCACAATTTTTCTTCTTTT } \\
\text { R: GATCTGCCATAGGTCTTACTTA }\end{array}$ & 46 & $300-350$ \\
\hline CarM079 & AY102430 & $(\mathrm{GA})_{15}$ & $\begin{array}{l}\text { F: TGCCGGTTCCATTCTCCA } \\
\text { R: ATGACCAGCTCGCCAGTGAT }\end{array}$ & 50 & $350-400$ \\
\hline CarM080 & AY102432 & $(\mathrm{GA})_{23}$ & $\begin{array}{l}\text { F: AACCTGCCGCCTCTTTC } \\
\text { R: TTGCGGGTAATAACTTCTCT }\end{array}$ & 46 & $100-170$ \\
\hline CarM081 & AY102433 & $(\mathrm{TC})_{11}$ & $\begin{array}{l}\text { F: GGAGAAAAGTGGACACGAACAGG } \\
\text { R: CAACGAAAATTAGACACAAGCAACT }\end{array}$ & 46 & $350-380$ \\
\hline CarM082 & AY102435 & $(\mathrm{CT})_{8}$ & $\begin{array}{l}\text { F: GTCCTGTTTTTGCCATGCCTTTAT } \\
\text { R: CACCCCTCTCCTGCTCAATCC }\end{array}$ & 46 & $350-370$ \\
\hline CarM083 & AY102436 & $(\mathrm{TC})_{16}$ & $\begin{array}{l}\text { F: TAAATCGCGTGTGGGGTAT } \\
\text { R: TTGGGAGTTAAAAGAAGGTT }\end{array}$ & 50 & $150-200$ \\
\hline
\end{tabular}




\begin{tabular}{|c|c|c|c|c|c|}
\hline SSR marker & $\begin{array}{l}\text { Accession number } \\
\text { (NCBI) }\end{array}$ & Repeat motif & Primer sequence $\left(5^{\prime}-3^{\prime}\right)$ & $\mathrm{AT}\left({ }^{\circ} \mathrm{C}\right)$ & $\begin{array}{c}\text { Allele size } \\
\text { (C. arabica L.) }\end{array}$ \\
\hline CarM084 & AY102437 & $(\mathrm{GA})_{17}$ & $\begin{array}{l}\text { F: CCCAAAATGAGGAAATAGCA } \\
\text { R: GGTGGGCCAATAATGACAA }\end{array}$ & 50 & $150-200$ \\
\hline CarM085 & AY102438 & $(\mathrm{AG})_{13}$ & $\begin{array}{l}\text { F: TAAGGGCTAGGAGGCAATAACC } \\
\text { R: ATAATCATCAACCAACCCATAAAAA }\end{array}$ & 46 & $350-400$ \\
\hline CarM086 & AY102439 & $(\mathrm{GA})_{14}$ & $\begin{array}{l}\text { F: AGCCGATATCTGACTGTTCTTTTC } \\
\text { R: CTTGGCCCTTCCTTGGTTTTT }\end{array}$ & 53 & $300-350$ \\
\hline CarM087 & AY102441 & $(\mathrm{GA})_{10}$ & $\begin{array}{l}\text { F: TTACATCCATCCGAAAACTT } \\
\text { R: CAGCACTGGCAAATAGCA }\end{array}$ & 46 & $250-280$ \\
\hline CarM088 & AY102442 & $(\mathrm{GA})_{11}$ & $\begin{array}{l}\text { F: CGGAACGTGCATTTACCTAC } \\
\text { R: TGGCCTATCTATTACAGCATTTG }\end{array}$ & 50 & $400-460$ \\
\hline CarM089 & AY102444 & $(\mathrm{TC})_{5}$ & $\begin{array}{l}\text { F: TACTGGGTTAAATTTATCGGGTGTT } \\
\text { R: AGGTTGGATGGTTAGTTTTGATGAT }\end{array}$ & 46 & $250-300$ \\
\hline CarM090 & AY102445 & $(\mathrm{GA})_{1}$ & $\begin{array}{l}\text { F: ATACAGCAATTTTGAGAGGAG } \\
\text { R: TATTTTGGATTATGTTATGACG }\end{array}$ & 46 & $250-280$ \\
\hline CarM091 & AY102446 & $(\mathrm{TC})_{19}$ & $\begin{array}{l}\text { F: TTGTGGGTATTGAAGTGAGC } \\
\text { R: CATCCCAAGCAAGAAGTGTA }\end{array}$ & 46 & $300-355$ \\
\hline CarM092 & AY102447 & $(\mathrm{GA})_{13}$ & $\begin{array}{l}\text { F: AGGCCAGACTTGTTTGATTTTG } \\
\text { R: GGCCCTTCTCGCTTTAGTTG }\end{array}$ & 53 & $200-300$ \\
\hline CarM093 & AY102448 & $(\mathrm{AG})_{23}$ & $\begin{array}{l}\text { F: CGCTAGCCAACGAGTGTAA } \\
\text { R: ATCCCAATTCTTTCTTTCTTTCTG }\end{array}$ & 46 & $200-230$ \\
\hline CarM094 & AY102449 & $(\mathrm{GA})_{30}$ & $\begin{array}{l}\text { F: GCCCGATATTCACTTCCTCCTTTCA } \\
\text { R: GATCCGCAACCTCCATTCAGTG }\end{array}$ & 50 & $400-440$ \\
\hline CarM095 & AY102452 & $(\mathrm{AG})_{18}$ & $\begin{array}{l}\text { F: GAAACCGTCAGTCCCAACA } \\
\text { R: CACTGAGGCACATGAATTTATCTAT }\end{array}$ & 50 & $300-400$ \\
\hline CarM096 & AY102453 & $(\mathrm{TC})_{24}$ & $\begin{array}{l}\text { F: TACTGGGGAAGAATTTATCATC } \\
\text { R: TTAGGCCATCCAAGAGTATTC }\end{array}$ & 50 & $280-320$ \\
\hline CarM097 & AY102454 & $(\mathrm{CT})_{18}$ & $\begin{array}{l}\text { F: GACTCAGCCGAATTCAAAGGTTAG } \\
\text { R:GAGGGGAAAAGAAAAGAATGAAGAA }\end{array}$ & 46 & $500-525$ \\
\hline CarM098 & AY102456 & $(\mathrm{TC})_{14}$ & $\begin{array}{l}\text { F: TGGCTCTGCATTCTGTCATA } \\
\text { R:ACCCGGAACCCACCAAAATAA }\end{array}$ & 46 & $200-260$ \\
\hline CarM099 & AY102457 & $(\mathrm{GA})_{24}$ & $\begin{array}{l}\text { F: AGAGCTGCGGTGGTGTCA } \\
\text { R: TATTAATACTCGCGGGGAAAAA }\end{array}$ & 46 & $250-270$ \\
\hline CarM100 & AY102458 & $(\mathrm{TC})_{17}$ & $\begin{array}{l}\text { F: GCTTGTGTAGAAAATTTTGGTGTAG } \\
\text { R: CTTCATCGGCATCTTCATCATCA }\end{array}$ & 50 & $500-540$ \\
\hline CarM101 & AY102459 & $(\mathrm{CT})_{28}$ & $\begin{array}{l}\text { F: TATGTCTCTAACTTTCCTATTTT } \\
\text { R: AGAGACTACATTTACACAGAAGA }\end{array}$ & 50 & $170-210$ \\
\hline CarM102 & AY102460 & $(\mathrm{CT})_{23}$ & $\begin{array}{l}\text { F: ACGGGGTGGAGGTTGGTG } \\
\text { R:GGAGGGGAAAAGAAAATAATGAAGA }\end{array}$ & 50 & $200-250$ \\
\hline CarM103 & AY102461 & $(\mathrm{CT})_{18}$ & $\begin{array}{l}\text { F: GCATTTTGGCCCTTCATTATTTTA } \\
\text { R: CATCCGCAACCTTCACCTG }\end{array}$ & 50 & $500-580$ \\
\hline CarM104 & AY102462 & $(\mathrm{CT})_{17}$ & $\begin{array}{l}\text { F: AGTTCCCTTAGCTTTTTCTTTC } \\
\text { R: CTTGACTTGGGACTTGTTATTTTG }\end{array}$ & 50 & $400-460$ \\
\hline CarM105 & AY102463 & $(\mathrm{GA})_{12}$ & $\begin{array}{l}\text { F: TGCTCCTACTAAATACCCAAACA } \\
\text { R: ATATGCCCAAGAAAATTAGATGAAA }\end{array}$ & 53 & $230-270$ \\
\hline CarM106 & AY102464 & $(\mathrm{TC})_{13}$ & $\begin{array}{l}\text { F: GATCCGTCAGCTTTTCCACCAT } \\
\text { R: AATTCACCGATCTTTGTTG }\end{array}$ & 46 & $200-240$ \\
\hline CarM107 & AY102465 & $(\mathrm{CT})_{11}$ & $\begin{array}{l}\text { F: TCTCGTCCGTATGAAACC } \\
\text { R: AGAGAAAAGGCTTGAAAACT }\end{array}$ & 46 & $100-140$ \\
\hline CarM108 & AY102466 & $(\mathrm{CT})_{11}$ & $\begin{array}{l}\text { F: CACCGATCATGAGCGTAGG } \\
\text { R: ACAACCACCACCACCACCACAC }\end{array}$ & 50 & $100-165$ \\
\hline $\mathrm{M} 20^{5}$ & - & $\begin{array}{c}(\mathrm{GA})_{5}(\mathrm{GT})_{8} \mathrm{TT}(\mathrm{GT})_{4} \mathrm{TT} \\
(\mathrm{GT})_{7}(\mathrm{GA})_{11}(\mathrm{TC})_{2}(\mathrm{CT})_{3} \mathrm{GT}\end{array}$ & $\begin{array}{l}\text { F: CTTGTTTGAGTCTGTCGCTG } \\
\text { R: TTTCCCTCCCAATGTCTGTA }\end{array}$ & 55 & $200-270$ \\
\hline M24 & - & $(\mathrm{CA})_{15}(\mathrm{CG})_{4} \mathrm{CA}$ & $\begin{array}{l}\text { F: GGCTCGAGATATCTGTTTAG } \\
\text { R: TTTAATGGGCATAGGGTCC }\end{array}$ & 55 & $150-180$ \\
\hline M25 & - & $(\mathrm{GT})_{5} \mathrm{CT}_{1}(\mathrm{GT})_{14}$ & $\begin{array}{l}\text { F: CCCTCCCTGCCAGAAGAAGC } \\
\text { R: AACCACCGTCCTTTTCCTCG }\end{array}$ & 57 & $160-170$ \\
\hline
\end{tabular}




\begin{tabular}{|c|c|c|c|c|c|}
\hline SSR marker & $\begin{array}{l}\text { Accession number } \\
\text { (NCBI) }\end{array}$ & Repeat motif & Primer sequence $\left(5^{\prime}-3^{\prime}\right)$ & $\mathrm{AT}\left({ }^{\circ} \mathrm{C}\right)$ & $\begin{array}{c}\text { Allele size } \\
\text { (C. arabica L.) }\end{array}$ \\
\hline M29 & - & $(\mathrm{CTCACA})_{4}(\mathrm{CA})_{9}$ & $\begin{array}{l}\text { F: GACCATTACATTTCACACAC } \\
\text { R: GCATTTTGTTGCACACTGTA }\end{array}$ & 57 & $10-120$ \\
\hline M32 & - & $(\mathrm{CA})_{24}$ & $\begin{array}{l}\text { F: AACTCTCCATTCCCGCATTC } \\
\text { R: CTGGGTTTTCTGTGTTCTCG }\end{array}$ & 57 & $90-135$ \\
\hline M47 & - & $(\mathrm{CT})_{9}(\mathrm{CA})_{8}(\mathrm{CT})_{4}(\mathrm{CA})_{5}$ & $\begin{array}{l}\text { F: TGATGGACAGGAGTTGATGG } \\
\text { R: TGCCAATCTACCTACCCCTT }\end{array}$ & 57 & $100-130$ \\
\hline
\end{tabular}

${ }^{1,2}$ Loci obtained with two enriched libraries; ${ }^{3}$ loci obtained from sequences published by Rovelli et al. $(2000) ;{ }^{4}$ loci obtained from published sequences in $\mathrm{NCBI} ;{ }^{5}$ loci obtained from sequences published by Combes et al. (2000). AT: Annealing temperature in Celsius degree. 
Table S2 - Allelic profiles of 19 coffee varieties and 6 interspecific hybrids obtained with 22 SSR polymorphic markers (1: Acaiá Cerrado MG1474; 2:Mundo Novo IAC 376-4; 3:Obatã IAC 1669-20; 4: Oeiras MG6851; 5: Ouro Verde IAC H5010-5; 6: Rubi MG1192; 7: Topázio MG1190; 8: Bourbon Amarelo IAC J22; 9: Bourbon Vermelho IAC 662; 10: Catuaí Amarelo IAC 62; 11: Catuaí Vermelho IAC 99; 12: Catucaí Amarelo 2015/cova479; 13: Catucaí Vermelho 2015/cova476; 14: Caturra Amarelo IAC 476; 15: Caturra Vermelho IAC 477; 16: IAPAR 59; 17: Tupi IAC 1669-33; 18: Icatu Amarelo IAC2944; 19: Icatu Vermelho IAC 2945; 20: CIFC H147/1; 21: CIFC 34/13(S353-4/5); 22: CIFC 832/1; 23: CIFC1343/269; 24: CIFC 110/5; 25: CIFC H539/8). \pm : specific alleles of Brazilian cultivars.

\begin{tabular}{|c|c|c|c|c|c|c|c|c|c|c|c|c|c|c|c|c|c|c|}
\hline SSR Locus & Allele & 1 & 2 & 3 & 15 & 4 & 10 & 11 & 14 & 5 & 6 & 7 & 8 & 9 & 12 & 13 & 16 & 17 \\
\hline \multirow[t]{2}{*}{ CarM096 } & 1 & & & & & & & & & & ++ & ++ & ++ & ++ & ++ & ++ & ++ & ++ \\
\hline & 2 & ++ & ++ & ++ & ++ & ++ & ++ & ++ & ++ & ++ & & & & & & & & \\
\hline \multirow[t]{3}{*}{ M20 } & 1 & ++ & ++ & ++ & ++ & ++ & ++ & ++ & ++ & ++ & ++ & ++ & ++ & ++ & ++ & ++ & & ++ \\
\hline & 2 & & & & & & & & & & & & & & ++ & & & \\
\hline & 3 & & & & & & & & & & & & ++ & & & & ++ & ++ \\
\hline \multirow[t]{7}{*}{ CarM101 } & 1 & ++ & ++ & ++ & ++ & ++ & ++ & ++ & ++ & & ++ & & ++ & ++ & & & ++ & \\
\hline & 2 & ++ & ++ & ++ & ++ & ++ & ++ & ++ & ++ & & ++ & & ++ & ++ & & & ++ & \\
\hline & 3 & ++ & ++ & ++ & ++ & ++ & ++ & ++ & ++ & & ++ & ++ & ++ & ++ & & & ++ & \\
\hline & 4 & & & & & & \pm & & & & & & & & & & & \\
\hline & 5 & & & & & & & & & ++ & & & & & ++ & ++ & & \\
\hline & 6 & & & & & & & & & ++ & & & & & ++ & ++ & & \\
\hline & 7 & & & & & & & & & & & & & & & & & ++ \\
\hline \multirow[t]{2}{*}{ CarM105 } & 1 & & & & & & & & ++ & ++ & & & & & ++ & ++ & & ++ \\
\hline & 2 & ++ & ++ & ++ & ++ & ++ & ++ & ++ & & & ++ & ++ & ++ & ++ & ++ & & ++ & ++ \\
\hline \multirow[t]{3}{*}{ CarM092 } & 1 & & ++ & ++ & & ++ & ++ & ++ & ++ & ++ & & ++ & ++ & ++ & ++ & ++ & ++ & ++ \\
\hline & 2 & ++ & & & ++ & & & ++ & ++ & & ++ & & & & & & & \\
\hline & 3 & & & & & & & & & & & & & & ++ & & & \\
\hline \multirow[t]{4}{*}{ M24 } & 1 & ++ & ++ & ++ & ++ & & ++ & ++ & ++ & ++ & ++ & & ++ & ++ & & & ++ & \\
\hline & 2 & & & & & ++ & & & & & & ++ & & & & ++ & & ++ \\
\hline & 3 & & & & & & & & & & & & ++ & & & & ++ & \\
\hline & 4 & & & & & & & & & & & & & & & & ++ & ++ \\
\hline CarM086 & 1 & & & & & & & & & & & \pm & & & & & & \\
\hline CarM001 & 1 & ++ & ++ & ++ & ++ & ++ & ++ & ++ & & & ++ & ++ & ++ & ++ & ++ & ++ & ++ & ++ \\
\hline CarM002 & 1 & & & & & & & & & & & & & & ++ & ++ & & ++ \\
\hline \multirow[t]{2}{*}{ CarM049 } & 1 & & & & & & & & & & & & & ++ & & & & ++ \\
\hline & 2 & ++ & ++ & ++ & ++ & ++ & ++ & ++ & ++ & ++ & ++ & ++ & ++ & ++ & ++ & ++ & ++ & \\
\hline \multirow[t]{7}{*}{ CarM052 } & 1 & ++ & ++ & ++ & ++ & ++ & ++ & ++ & ++ & ++ & ++ & & ++ & ++ & ++ & ++ & & ++ \\
\hline & 2 & & & & & & & & & & ++ & & & & & & ++ & \\
\hline & 3 & & & & & & & & & & & \pm & & & & & & \\
\hline & 4 & & & & & & & & & & & & ++ & ++ & & & & \\
\hline & 5 & & & & & & & & & & & & ++ & & & & ++ & \\
\hline & 6 & & & & & & & & & & & & & & & & & ++ \\
\hline & 7 & & & & & & & & & & & & & & & & & ++ \\
\hline \multirow[t]{5}{*}{ CarM051 } & 1 & ++ & ++ & ++ & ++ & ++ & ++ & ++ & ++ & ++ & ++ & ++ & & & ++ & ++ & & ++ \\
\hline & 2 & ++ & ++ & ++ & ++ & ++ & ++ & ++ & ++ & ++ & ++ & ++ & ++ & ++ & ++ & ++ & & ++ \\
\hline & 3 & & & & & & & & & & \pm & & & & & & & \\
\hline & 4 & & & & & & & & & & & & ++ & & & & ++ & ++ \\
\hline & 5 & ++ & ++ & ++ & ++ & ++ & ++ & ++ & ++ & ++ & & ++ & ++ & ++ & ++ & ++ & ++ & ++ \\
\hline \multirow[t]{2}{*}{ CarM050 } & 1 & ++ & ++ & ++ & ++ & ++ & ++ & ++ & ++ & & ++ & & ++ & ++ & & & ++ & \\
\hline & 2 & & & & & & & & & ++ & & ++ & & & ++ & ++ & & ++ \\
\hline CarM065 & 1 & ++ & ++ & & & & & & & & ++ & ++ & ++ & ++ & ++ & ++ & ++ & ++ \\
\hline CarM070 & 1 & ++ & ++ & ++ & ++ & ++ & ++ & ++ & ++ & & ++ & ++ & ++ & ++ & ++ & & ++ & ++ \\
\hline
\end{tabular}




\begin{tabular}{|c|c|c|c|c|c|c|c|c|c|c|c|c|c|c|c|c|c|c|}
\hline SSR Locus & Allele & 1 & 2 & 3 & 15 & 4 & 10 & 11 & 14 & 5 & 6 & 7 & 8 & 9 & 12 & 13 & 16 & 17 \\
\hline \multirow[t]{2}{*}{ CarM069 } & 1 & & & & & & & & & & & & & ++ & & & & \\
\hline & 2 & ++ & ++ & ++ & ++ & ++ & ++ & ++ & ++ & ++ & ++ & ++ & ++ & & ++ & ++ & ++ & ++ \\
\hline CarM068 & 1 & & & & & & & & & & & & & & ++ & & & \\
\hline \multirow[t]{5}{*}{ CarM048 } & 1 & & & & & & & ++ & & & & ++ & & & & ++ & & ++ \\
\hline & 2 & & & & & & & & & & & & ++ & & & & ++ & \\
\hline & 3 & & & & & & & & & & & & & ++ & & & & \\
\hline & 4 & ++ & ++ & ++ & ++ & ++ & ++ & ++ & ++ & ++ & ++ & ++ & ++ & ++ & ++ & ++ & & ++ \\
\hline & 5 & & & & & & & & & & & & & & & & & ++ \\
\hline cmp3 & 1 & & & & & & & & & & & & ++ & ++ & & & & \\
\hline \multirow[t]{2}{*}{ cmp6 } & 1 & & & & & & & & & & & & ++ & ++ & & & & \\
\hline & 2 & ++ & ++ & ++ & ++ & ++ & ++ & ++ & ++ & ++ & ++ & ++ & & & ++ & ++ & ++ & ++ \\
\hline cmp10 & 1 & & & & & & & & & & & & ++ & ++ & & & & \\
\hline NTCP8 & 1 & & & & & & & & & & & & ++ & & & & & \\
\hline
\end{tabular}

